doi:10.29285/actapinteriana.2020.6.47

\title{
Szedő Dénes ferences költő portréjához ${ }^{1}$
}

\author{
Zatykó László OFM \\ Szegedi Ferences Rendház, 6725 Szeged, Mátyás király tér 26. \\ zatykolaszlo@gmail.com
}

Zatykó L. (2020): Szedö Dénes ferences költö portréjához. To the portrait of the Franciscan poet, Dénes Szedö. Acta Pintériana, 6: 47-71.

\begin{abstract}
The author of the study aims at presenting the Franciscan poet's, Dénes Szedö's path of life and his poetry's features. Studying his diaries the author has found the essence of Szedö's poetry in the capability for the contraries' uniting in harmony and balance through tensions' release (coincidentia oppositorum). His poetry and path of life unfolding through his diaries written in his last thirteen years in the monastery in Pasarét (Budapest) were shaped by his Jewish origin and the social and political environment in Hungary before the World War II., his mother, his friends and models (for example Béla Bartók, Zoltán Kodály or Antal Szerb). His brothers in Pasarét and his friends could also experience Dénes Szedő's personality uniting contrary features (patriotism and homelessness, farewell and staying, sadness and jollity). Although he had tried to escape from his fate determined by his life experience and his personality many times in his strenuous life, his notes in the diaries refer such a Franciscan poet who found his own path among the poor and the fallen in Hungary. He could harmonize the contrary features of his personality, and as St. Francis sent his brothers to sing Lord's praise, Dénes Szedő could become a ,,joculator Domini” in the 20th century.
\end{abstract}

\section{I. „Feltünni félek” \\ (Zsolt 131,1 - ford. Szedő Dénes)}

Szedő Dénes életmüve az „Összes müvei” kiadásával, halála után több mint harminc évvel lesz megismerhető. E késedelem semmiképpen sem a müvek értékelésével, még csak nem is e müveket gondozók tehetetlenkedésével magyarázható, hanem azzal, hogy a szerző tehetséges rejtőző.

Az „Összes müvei” első kötete, a Müfordítások fülszövegében írja Hidász Ferenc:

„Egry József Breviáriumában talált rá arra a mondatra, melyet müvészi hitvallásának tekinthetünk: 'Nem tudom, az értékes emberre melyik kitüntetöbb, a mellözése, vagy a kitüntetése?' Élete második felében, amikor 'törvényen kivüli barát' lett (1950), ö az elöbbit választotta."

E választást megelőzte, megalapozta élete döntő választása, élete döntő fordulata, melyröl az $A z$ egyszerüség útja / Facimbalom fülszövegében maga írja: 


\section{„Életem egyik nagy - ha nem a legnagyobb - ajándéka az volt, hogy szent Ferenc a családjába fogadott."}

Assisi Szent Ferenc testvéreként, Jézus szenvedélyes követőjeként, melyröl azt írja az imádságáról valló írásában, hogy „,csak a szerelemhez hasonlíthatom”, nagyra tartotta az alázat méltóságát, ezért akart mindenkinél „kisebb testvér” lenni. Undorodott az első helyekért való farizeusi, gőgös tülekedéstől, a bünbánó vámos módjára a rejteket, az utolsó helyet kereste. Szívből, hallelujás örömmel azonosult az isteni ítélettel:

„Fennhéjázót elmarasztal, alleluja, Alázatost felmagasztal, alleluja."

(Magnificat parafrázis)

Riadozott minden reflektorfénytöl, nagyobb, igazabb fényre vágyott, arra, hogy Urának szemefénye legyen:

„Mint vad a víz hüvösére,

Vágyik az erdei érre,

Vágyom a mennyei fényre."

(Zsolt 41, parafrázis)

Egyetlen tetszést keresett:

„Ura intésére figyel a hü szolga,

Tetszésére lenni legeslegföbb gondja."

(Zsolt 122, parafrázis)

Nem akart e világ feldobott, ünnepelt bölcseivel egy követ fújni, inkább választotta Isten lenézett, hátravetett „balgaságát”, mely felülmúl minden emberi bölcsességet. Életeszményét a Merre? c. versében foglalja össze:

\section{„Lefelé / Hátra / Befelé / Balra / Alleluja."}

Nem vágyott hírre, hírességre, minek is, hiszen ő mindenestül a „Jóhír” embere volt, élő evangélium, a boldog szegény, a boldog tékozló fiú az atyai házból:
„Idegen vagy bár,
$s$ üres kézzel állsz,
kiaszott fa mégse vagy.
Hozzám szegödtél:
szent hegyemre viszlek,
házamba helyezlek,
térdemen ringatlak.
Ne félj!”

\section{Coincidentia oppositorum}

A naplóra oda kell figyelni. Csoóri Sándor írja Naplók - háttérben Máraival c. írásában, hogy

„,naplót írni és imádkozni csakis komoly eltökéltséggel érdemes. Alázattal s nagy-

nagy fegyelemmel. " (CSÓRI 2007, p. 124)

Szedő Dénes élete utolsó tizenhárom évében, tenyerében megférő kockás noteszekbe írta naplóját, „alázattal és nagy-nagy fegyelemmel”. És, ahogyan ez Szedő Gáspár papírkereskedő fiához illik, minden füzetet, az első laptól az utolsóig gazdaságosan kihasznált, telis-tele írta apró, gyönyörüen rajzolt, önarckép-értéküen karakteres betüivel. Ez alól csak az utolsó, a huszonnegyedik (!) füzet a 
kivétel, amelyik az egyharmadánál vége szakad. Szedő Dénes megismerése szempontjából mégis e „torzó-füzet” különös kincs. Mi az, amit az utolsó hónapokban fontosnak tartott? Mi az, amit ezeken az utolsó lapokon (napokon) aláhúz, akár pirossal is, bekeretez, reszkető kézzel meg-megismétel?

Ilyen ez a két szó: coincidentia oppositorum. Négyszer találjuk leírva. Először pusztán ennyi megjegyzéssel: „,Ellentétek egysége”. Másodszor egy „egyperces homília” részeként olvasható. Szedő Dénes azokat a homíliáit nevezte így, melyeket a parányi szobájában bemutatott szentmiséken, a kéthárom főből álló hívőseregnek mondott el. Az elnevezés Örkény egyperceseire utal. Mivel a diktatúra diktálta szerzetesi keretbe ő nem fért bele, Pasaréten a ferences kolostoron kívül húzta meg magát, befogadottként egy „ici-pici cselédszobában”, mellyel nagyon meg volt elégedve. Nekünk, kereten belül élő fiatal ferenceseknek úgy tünt, hogy ő kívül élve is beljebb jutott Assisi Szent Ferenc lelkületének megélve-megismerésében. Így lett többünknek lelki vezetője, tanítója, mestere. Egyik homíliájában Jézus utolsó vacsorán elmondott beszédjének következő mondatához füz magyarázatot:

, 'Békességet hagyok rátok. Az én békémet adom nektek. Nem úgy adom nektek, ahogy a világ adja' (Jn 14,27).

- Az embereknek meleg csönd kell, és hideg zürzavart, kavarodást, gyülöletet ad nekik a világ. Mi hoz békét? Krisztus útmutatásai, miket a szeretö szív befogad [...]. Salom: béke, összhang. Disszonáns hang nélkül nem születik harmónia. Az igazi béke sosem közöny, nem is idill, hanem coincidentia oppositorum: egyensúly és arány, feszültségek feloldása." (Kézirat)

Harmadszor Pascal azon gondolatához füzött magyarázatként olvashatjuk a két szót: coincidentia oppositorum, miszerint a szélsőségek találkoznak Istenben (vö. PASCAL 1978, II,72). Szedő Dénes gondolkodásában előkelő helyet kap Areopagoszi Dénes (V. sz. vége - VI. sz. eleje) apofatikus (negatív) teológiája, mely azt tanítja, hogy Istenről csak az állítás és tagadás dialektikájában lehet beszélni.

„Istenem, te vagy a szeretet -, de valami egészen más fajta szeretet. Te vagy az igazság -, de valami egészen másfajta igazság"

- olvassuk ebben a Naplófüzetben.

Jézusban is ez az ellentétek egysége ragadja meg. Hogyan hagytam el a világot c. írásában erről így vall:

„Már felsös gimnazista koromban került kezembe Máté evangéliuma. Olyan volt, mintha szerelmes levelet kap valaki. Föleg a Hegyi Beszéd nyügözött le. Hisz itt minden másképp és forditva volt, mint ahogy eddig hallottam: a szegénynek jó meg a sírónak, az éhesnek és az üldözöttnek. Jézus senkire sem hasonlitott az égvilágon. - Bolond ez az ember, vagy csakugyan a Messiás? Különb mindenkinél. Belészerettem. (Bocsánat: nincs jobb szó rá.) Valahogy jólesett az is, hogy zsidó volt, vagyis megvetett fajzat." (SZEDÖ 1983c)

Beragasztja ebbe az utolsó füzetébe egy régebbi, az Új Emberben megjelent Kép és hasonlatosság c. írásának (1972. I. 23.) Jézus arcát megfestő sorait, megváltoztatva a címet arra, hogy Coincidentia oppositorum:

„Egyszerre rokon és idegen, távoli és közeli, erös és erőtlen, indulatos és szelid, szigorú és megbocsátó, nyers és gyöngéd, nagyvonalú és a csekélyet is számonkérő. Veri valóban minden fantáziánkat, elüt mindenkitöl, csak önmagával rímel: maga a teljesség."

Az eredeti tanulmányban ehhez még hozzáfüzi:

„,alán csak egy ellenpontok feszültségére épült Bach-fúga megbonthatatlan rendje, végsö harmóniája adhat róla némi fogalmat". 
Szedő Dénes Jézus tanítását ilyen ellenpontokban ábrázolja Viruló igék - Igen és Nem c. kétsorosokból álló ciklusában.

\section{A mesterek}

Azokat tekintette Szedő Dénes mestereinek, akikben fölfedezhette az ellentétek jézusi egységét, akik ezt az egységet megélték, megénekelték. A Nyugat 1922.3. számában Bartók Béla zenéjéről ír. Kiemeli a gyöngédség és a gátakat áttörő hatalmas erő egységét:

„Szelidség és elemi erö egyesül egy örök gyermekben. Íme a bibliai kép, amelyben báránnyal lakozik az oroszlánkölyök ..., és egy kis gyermek örizi azokat." (SZEDÖ 1922b, p. 226)

Fölfedezi a „szükszavú tömörség” és a pazar virágba borulás egységét:

„Több foglaltatik benne, mint amennyit kifejez. [...] A lényegesre szoritkozván, mindig csak a magvát adja, sohasem a virágját. De szinte pillanatok alatt serken bennünk ez a mag virággá." (SZEDÖ 1922b, p. 226)

Szedő Mihályt - ez a keresztneve - 1921 februárjában, érettségije évében éri az a megtiszteltetés, hogy a Nyugatban - a legnagyobbak, Móricz, Kosztolányi, Babits stb. között - megjelennek az írásai. Ezek az írások, különösképpen is a versek, nem érettek, és a következő számokban megjelentek sem. Osvát Ernő írót-nevelő zsenijét dicséri, hogy mégis támogatta megjelenésüket, mert egy-egy kivillanó sorban, szófordulatban, képben meglátta a jövő ígéretét. Ilyen ígéretes mondat e Bartók-kritika utolsó megállapítása is:

„Az a vérlázitó fogadtatás, amelyben a Zeneakadémiát megszálló közönség ezt a müvet részesitette, szomorú tanúság amellett, hogy nálunk nagyrészt csak azoknak van hangverseny-látogatni módjuk, akiket nem illet."

(SZEDÖ 1922b, p. 227)

A későbbi, 1955-ben magyarul, majd 1956-ban franciául is megírt Bartók-versével - Dallam ködgomolyagban - Szedő Dénes igazolja Osvát Ernő prófétai meglátásának és bátorságának helyességét. Amit Osvát még csak reménységként láthatott, azt Weöres Sándor beteljesedésként:

„Vedd tudomásul, Dénes, hogy a legjobbak egyike vagy!"

Kodály Zoltánban is az ellentéteket egyesítő nagyságot látja meg, és tiszteli:

„Volt benne valami krisztusi. Nem csak külsejében - ez sokaknak feltünt-, hanem legbelsöbb, rejtett lényében is. Távoli volt és közeli, gyöngéd és kérlelhetetlen, szükszavú és szókimondó, komoly és derüs, nagyvonalú s a legcsekélyebbet sem elhanyagoló. De nemhogy most ilyen, máskor meg olyan lett volna: egyszerre volt ö ilyen is, amolyan is. A haragvó- szelíd Jézus képét ezért tudta zenéjében is úgy megörökiteni, mint kivüle senki más."

(Szedő 1983b)

Ez a Kodályról szóló visszaemlékezés - évekig nem jelenhetett meg, mert nem volt hajlandó az ötvenhatos forradalmat csak forradalomként említeni - hálát is rejt. ${ }^{2}$ Ahogy annak idején Osvát Ernő fedezte fel az ifjúkori zsengékben szunnyadó nagy költőt, úgy Kodály ébresztette fel Szedő Dénesben a novíciáttal, a ferences rendbe lépéssel - mintegy másfél évtizedre - elhallgató költőt. Nem kaphatott Kodály ébresztő, serkentő barátsága szebb és nagyobb visszaigazolást annál, mint a neki ajánlott és róla szóló Örszem c. vers, melyet Kodály müve, a Zrínyi szózata ihletett. 


\section{Barabások}

Az ellentéteket egységbe rendező gondolkodás- és szemléletmód kialakulásában jelentős szerepe volt az 1920-tól formálódó baráti körnek, melynek egyik alapvető jellemzője épp a coincidentia oppositorum volt. Magukat, egy korabeli sláger után (Add nékem egy lány édes ifjúságát c.) Barabásoknak hívták. Többnyire a Szedő testvéreknél jöttek össze. Mihály és László mellett ott találjuk Juhász Vilmost, a későbbi vallás- és művelődéstörténészt, aki 1946-ban indítja újra a Vigiliát, majd 1949-ben New Yorkba emigrál; valamint Sárközi Györgyöt, aki mélyen hívő katolikus, az egész népi irodalom szellemi vezére lesz, a Magyarország felfedezése sorozat elindítója, aki magyar sorskérdésnek tekintve szolgálja a magyar parasztság szellemi, kulturális és gazdasági fölemelésének ügyét. A nemzetnek tett szolgálatait, zsidó származása miatt, halállal büntetik. A 46 éves író a balfi pokolban élete árán, szó szerint a végkimerülésig segíti, menti a társait. A társaság legfiatalabb tagja Szerb Antal, öt 44 évesen vertek agyon. Ugyanott és ugyanazon okból ölték meg, mint Sárközi Györgyöt. Öróluk írja Szedő Dénes 1948-ban a Curriculum vitaejében, hogy ők , voltak és maradtak a legjobb barátaim” (SZEDŐ 1948 in BOROVI 2001, p. 264).

Erről a baráti körről olvashatjuk Szerb Antal Könyvek és ifjúság elégiája c. írásában, hogy „,mélységesen komolyak voltunk, [...] férfiasak, patetikusak és átmenetileg nagyon vallásosak voltunk, templomba járó áhítatossággal. Többen közülünk szerzetesek lettek, a legkomolyabbak, legértékesebbek." (SZERB 2002, p. 161)

Itt nyilván a két Szedő testvérre gondolt: Lászlóra, aki később kármelitaként a Szeverin nevet kapta és Mihályra, aki ferencesként a Dénes nevet választotta. Igaza van Poszler Györgynek, Szerb Antal kiváló monográfusának:

„A Barabások útkereséseinek szinképe egyesit magában minden árnyalatot [...], de mégis közös bennük a fennálló valóságot tagadó, lázadó attitüd."

(POSZLER 1962, p. 383)

Erről a lázadásról írja Szerb Antal a már idézett esszéjében:

„Éreztem, hogy a romokon [az 1920-as években vagyunk - Z. L.] bizonnyal új világ fog most felépülni, egy fantasztikus világ, amelyet nem a felnöttek fognak feltérképezni, ahol minden lehetséges lesz, a fiatalok világa, a nyolclábú borjak és éneklö üstökösök diadalmas birodalma jön.” (SZERB 2002, pp. 159-160)

A lelkesedés-lázadás közösségét és a gondolkodások különbözőségét Sárközi György Barabásoknak ajánlott, Fiataloknak c. verse így fogalmazza:

„Mindnyájan egyet énekelünk, mint a virágok egy napra nyilnak,

S mégis ezer színnel táplálja öket a föld,

Más-más zenével mindnyájan egyet énekelünk, igaz torokkal. [...]

S úgy összehangzik minden, mint szivárványban a szín."

(SÁRKÖZI 1921, p. 371, 3. \& 6. vsz.)

Mit nyer, mit kap Szedő Dénes ettől a baráti körtől, ezektől a barátaitól? A legnagyobb ösztönzést, bátorítást, bizonyosságot és megerősítést abban, hogy a legösszeegyeztethetetlenebbnek kikiáltott valóságok is összhangba hozhatók, és éppen ez a törekvés, pont ez az istenien emberi, a krisztusi, amely vállalja, hogy az „,ellentétek keresztezési pontja "3 legyen, mert „,igaz egész csak ellentéteiddel együtt lehetsz" (Tao Te King, 25. vsz. - ford. Szabó Lőrinc). Szedő Dénes arcát, alakját, személyiségét, munkásságát nem írhatjuk le jobban, mint az utolsó Naplófüzet sokszor ismételt két szavával:

Vas István így fordítja a coincidentia oppositorumot (Nicolaus Cusanus sírja). 
coincidentia oppositorum. Ennek semmi köze az összemosáshoz, a csalárdságból, vagy igénytelenségből fakadó megalkuváshoz, a mindegy közönyéhez.

„Kodály nekem azt tanitotta, hogy ezt a szót, hogy mindegy, töröld ki a szótáradból!"”

- mondta Szedő Dénes, feddőleg, amikor igényességre akart tanítani. Az igen és a nem csak akkor hozható egybe, ha az igen valóban igen, a nem valóban nem.

\section{Jézus nemzetségében}

Szedő Dénesben a Krisztus Jézust követő keresztény, azaz krisztusi ember és a szent hagyományokból élő zsidó nem áll szemben egymással. Jézusban, a Vele közös sorsban, ennek vállalásában lesz vállalható, megélhető, kiteljesíthető az a küldetés, amelyröl az utolsó füzetben, e csonka-kincstárban ír: „,vri anochi - héber vagyok én” (Jón 1,9). És ahogy Jézus a Jónás sorsával értelmezi önmaga küldetését (Mt 19,39-41), úgy értelmezi, érti meg a maga küldetését Szedő Dénes Jézus sorsában, a Jézussal való sorsközösségben. Nem véletlen, hogy az újszövetségi Szentírásból azok a helyek állnak hozzá legközelebb, azokat a helyeket fordítja le magának, melyek ebben adnak eligazítást (Jn 1,1-14; Fil 2,6-11; 1Pét 2,21-24).

Szedő Dénes szemléletében Jézus, a pátriárkák, a próféták világa nem két világ, hanem egymásban, egymásból élő egyetlen világ, az Egyetlené. Ezt az egységet ámulja, amikor lefordítja Meliton szárdeszi püspök (†190) A föláldozott Bárányról c. beszédét. Ebben olvassuk:

„Sokakban sokat elszenvedett Krisztus. Ábelben megölték, Izsákban gúzsba kötötték, Jákobban elbujdosott, Józsefben eladták, Mózesben kitették, a bárányban megkötözték, Dávidban üldözték, a prófétákban meggyalázták." (SZEDÖ 2011, p. 466)

Szedő Dénes nem tudja önmagát nem Jézusnak, a szenvedésben diadalmas szolgának sorsában szemlélni. Szentírásában a szenvedő szolgáról szóló negyedik éneket (Iz 52,13-53,12) oldalt végigvégig megjelöli, kijelöli magának. Az ének bevezető és befejező soraihoz ${ }^{4}$ glosszaként odaírja: „A szolga megdicsöül”. Kerényi György zeneszerzővel 1951 és 1953 között folytatott levelezéséböl kiderül, hogy egy Márk-passión dolgoztak. A Facimbalomban megjelent verseinek egy része ${ }^{5}$ és sok jelentős, tudomásom szerint meg nem jelent vers $^{6}$ korálként, illetve áriaként szerepelt volna az oratóriumban. Szép feladat volna felkutatni ezek dallamait a Kerényi-hagyatékból. A záró kórusban felhangzott volna $A$ Bárány menyegzóje c. vers:
„Szivárvány hídján
halad a Bárány;
szarván a nap.
Követi népe
fürösztve vérbe,
fehér csapat.
Száz hárfa zendül,
száz pálma lendül:
'Gyözött az Úr!'

\footnotetext{
„Nézzétek, szolgám diadalmaskodik [...] látni fogja a világosságot” (Iz 52,13; 52,11; ld. Iz 52,13-15; 53,11-12). A bárány, Az elhagyatott, A hallgató Ige, A templom, Ki rést ütöttél, Kakasszó, Ubi caritas.

A megölt bárány, Korál, Getszemáni kertje!, Méla olajfák közt, Feljött már esthajnal csillaga, Íme az asszony, Irgalom-Kegyelem.
} 


\section{'Véren vett kincsem \\ vegyétek ingyen \\ ajándokul!'”}

Szedő Dénes mindenek előtt Jézusért szereti zsidó-voltát. Ezért benne egy szemernyi sincs abból a disszonáns érzületből, melyre Szerb Antal naplójának 1942. V. 21-i bejegyzése utal:

„A zsidóság, mint elnyomott kisebbség, szeret dicsekedni azzal, hogy mi mindent 'adott az emberiségnek'; ô adta Heinét, Meyerbeert és Einsteint stb. Ez mind szép, de nagy emberei a legtöbb népnek voltak. A zsidóság tragédiája az, hogy nem dicsekedhet a legnagyobbal, amit adott, Jézussal és a kereszténységgel."

Szedő Dénes ezzel a legnagyobbal dicsekszik (vö. Gal 6,14).

\section{4. „Hazám”}

Személyében az otthon és otthontalanság, haza és hazátlanság kettőssége harmóniába rendeződik: mindkettőnek helye van. A már említett Curriculum vitaeben a következőt írja az édesanyjáról, Weisz Rózáról:

„Nagy nemzeti géniuszaink s az európai kultúra szeretetét oltotta belénk."

(SZEDÖ 1948 in BOROVI 2001, p. 264)

Szedő Gáspárné a Budapest VI. kerületi Lovag utcai polgári leányiskolában tanított magyart és történelmet. Az iskola az 1934-1935-ös Értesítőjében méltatja Szedő Gáspárnét. Egy - feltehetően szakfelügyelői jelentés számol be egy órájáról, melyben épp Kölcsey Himnusza volt a téma:

„,Mély csend és figyelem. A táblán egyetlen szó: Himnus. És megindul az óra. És megszólal a tanár. És nyílnak gyermeki ajkak és lepereg elöttünk ezer év történelme, felhangzik nemzetünk évezredes jajja, véráztatta földünk minden rögének siralma. Vérzivatarok száguldanak fejünk felett. Tatárhordák, török csordák, német ármány, turáni átok - és magyar diadalok, magyar dicsőség. Néha tiz hang egyszerre, máskor néma csend. Kérdések, feleletek, elfojtott akarások és felszabaduló energiák. A végsökig feszült hangulat. Mintha szárnya nöne egy-egy gyermeki szónak, mintha ólomsúllyal nehezedne lelkünkre egy-egy fájó kérdés. Miért, hogy ennyi szenvedés, ennyi 'villám dörgö fellegekben'? [...] Itt a magyar nemzet képe formálódott ezer év távlatából. [...] Szedö Gáspárné nem mesterembere, de müvésze a pedagógiának. Kezének egyetlen rezdülése templomi csendet teremt. Áhitat üli meg hallgatóinak lelkét, ha néma csendben áll és lelkesedés forrását nyitja, ha megszólal."

(A Budapest VI. kerületi Lovag utcai polgári leányiskola Értesitöje, 1934-1935)

Azért idéztem ilyen hosszan ezt az Értesitőt, mert választ találunk benne arra a kérdésre, hogyan forr egybe egy emberben Izrael géniuszainak és a nemzeti géniuszainknak a szeretete. Úgy, hogy mindkettőt ez a nagy nevelö, az édesanya ültette el gyermekeinek a lelkében.

Már az első, a Nyugatban megjelenő írásaiból kiérződik az otthonról hozott, ezért erős hazaszeretet, magyarságtudat. A már említett Bartók-esszét kezdi ezzel a kijelentéssel: ,, Szentebb nékünk a magyar lélek” (SZEDÖ 1922b, p. 226), s aztán a „magyar lélek” egy jellemzőjét elemzi Bartók zenéjében:

„Valami dac jellemzi ezt a zenét, joggal nevezhetnök magyar dacnak, amelyet egyedül a magyar 'keserves' szó jelöl." (Uo.) 
Ugyanebben az évben jelenik meg a Nyugatban az Ananké címü, harsány képektől burjánzó szabad verse, mely a trianoni békediktátum után idegenbe szakadt magyarságot siratja. A magyar „,keservest” egyrészt a görög mitológia képeivel mutatja be, másrészt egy bibliai képpel, utalással a választott nép babiloni fogságára: „,mi hárfánknak megtéptük húrjait, Idegennek közepette” (SZEDŐ 1922a, p. 484). E sor a 137. zsoltárt idézi fel:
„Babilon vizeinél ültünk sirva
Siónra emlékezvén;
Hárfánkat rendre fölaggattuk
környezö füzfák ágbogára [...]
Hogyan zengjük az Úrnak énekét
idegen földön?"

(Szedő Dénes fordítása)

Ez a kettős egybevetés kiemeli a magyar sors-tragédiát a provincializmusból. Az utolsó versszakban egyszerre van jelen a részvét, de benne van az üres ígéretekkel biztató irredenta láz rejtett, de annál erélyesebb bírálata is:
„Mire szeressük
mi ezt a földet? Mely szüleinktöl elrekesztett, bánatunkkal körül árkos.
Kegyetlen
rajtunk az istenek korbácsa: vágyaink kedvezö szelével indít immár
hazatérnünk, de számunkra az otthon nem a Labdakidák iszonyú átkával biztató föld-é?"”

(SZEDÖ 1922a, p. 484)

A hazaszeretetnek azt a szellemiségét tükrözik e sorok, melyről Simone Weil nyomán Pilinszky ír:

„A hazát csak egyféleképpen lehet és szabad szeretni. Úgy, ahogy azt a népdalokban, Homérosznál vagy az evangéliumok szenvedéstörténetében olvashatjuk. A hazát egyedül részvéttel szabad és lehet szeretnünk."

(PILINSZKY 1977)

Ez a mondat a Naplóban többször előfordul.

Szedő Dénes hazaszeretete igen rokon azokéval, akik őt kitaszítottságában „részvéttel” tudták szeretni. Amikor 1950-ben egyik napról a másikra a kolostorból az utcára kerül, Borsos Miklósék fogadják be, Illyésék és Németh Lászlóék segítik, a civil ruháit is e jó barátok hordják össze. A Kodálytól kapott fekete inget úgy viseli, mint prófétafi a mester palástját. E barátaira úgy tekintett e „,csillagoltó sötétségben” (Vajda János), mint akik maguk a csillagok. Minden felfénylésükre azonnal felfigyelt.

Elsőként került a kezébe, magától a szerzőtől kapta ajándékul, Illyés Gyula 1950-ben vagy 51-ben írt „életveszélyesen” nagy verse, az Egy mondat a zsarnokságról. Kincsként őrizte és küldetésesen terjesztette. Én is nála olvashattam.

1955. december 16-án hangzik el a rádióban Kodály hatalmas kórusmüve, a Zrínyi szózata, rá két napra pedig a Zeneakadémián, zendülésnek felfogható fogadtatással. Fótról, 1955. december 29-én keltezett levelében már ezt írja Szedő Dénes Kerényi Györgynek:

„Fót hátán fót lettem magam is idöközben [...] dúdolom a Zrinyi szózatát. Végre egy nagy tett, száz év óta a legnagyobb. " (SzEDÖ 1955)

És e „nagy tett” nagy tettet ihletett, az 1956 januárjában írt nagy verset, Az őrszem címüt, mely félreérthetetlenül Kodályról szól. Ez még nyilvánvalóbb a vers első változatában:

„Felkiált mégis egy

agg örszem, s zeng a hegy!' 
- s rá zendült a nép. „Rázendült”, így látta ezt Révai József elvtárs, az Elnöki Tanács helyettes elnöke is, aki egy, 1957 nyarán tartott pártértekezleten, kiborulva Kodály új Kossuth-díján, majdnem (az „ellen”-t leszámítva) igazat mondott:

„A Ne bántsd a magyart [...] az ellenforradalom szellemi elökészitésének fejezetéhez tartozik."

Ugyanebben a hónapban készül el a Bartókról szóló, nem kevésbé nagy vers, a Dallam ködgomolyagban francia változata. E versében a haza fogalma, valósága szellemibbé, lelkibbé is válik, szívben élő valósággá. A haza ott van az érte viselt hazátlanságban és az érte szenvedett otthontalanságban is:
„Fülel egy belsö dalra, a tengeren át hallja, ahogy zengeti tisztán egy ürögi parasztlány. '”

Ugyancsak egy Kerényi Györgynek 1957. január 7-én írt levélből tudjuk, hogy az '56-os forradalmat verssel köszöntötte:

„Sokat gondoltam rád a lezajlott hösi s e gyászos mái napokban. E kis vers tanúskodjék róla."

Ez az október 25-én írt vers az egyetlen hely Szedő Dénes költészetében, ahol a hazaszeretete, a „részvét” vallomásosan nyilvánul meg:
„Kattog, robban ismét
minden körülem.
Kattog, ráng és reszket
belé a szivem.
Mely ott zúg, az ólom,
gyilkolva Budán,
csépel, szab engem is
vadul-ostobán.
Csüggök lobogódnak
csupasz árbocán
maradék szivemmel,
vértanú hazám!"

Az idézett levél ezzel zárul:

„Babits szavaival vigasztalom magam: Zsibbad a szabadság, de titkon bizsereg, és jön az igazság közelebb, közelebb” (SZEDÖ 1957),

és e két sorba beleértette az egész Áldás a magyarra c. verset, benne e három sorral:

„Erös igazsággal az eröszak ellen:

igy élj, s nem kell félned, veled már az Isten.

Kelnek a zsarnokok, tünnek a zsarnokok."

Ekkor fordította le Alphonse Métérie a Les Nouvelles Litteraires 1956. dec. 20-i számában megjelent, a magyar szabadságharcot sirató Karácsony c. versét, melynek nyitó versszaka így hangzik:
„Glóriát zengni ma
jó szívvel ki akad?
Fát diszitsen? A fa
holtakkal roskatag!" 
Sajnos még nem veszítették aktualitásukat ezek a sorok:

„, Sötét ál-mágusok!

az arany, tömjén, mirrha,

mit eloroztatok:

zsarátnok, könny és vér ma!"

Németh László 1964-ben írt Négy próféta címü verses drámáját méltató esszével köszöntötte. Az esszé rávilágít e dráma egyenesen nekünk szóló üzenetére, arra, hogy miképp lehetséges ,, a kis nép nagy sors csodája". Arra,

„, hogyan válik országa pusztulása révén, bünhődés és megtisztulás által e nyakas és 'körülmetéletlen szivü' nép nemzetek fölötti nemzetté, a Messiás szálláscsinálójává. A külső hanyatlás és pusztulás görbéjével szemben a belsö fölemelkedés és átszellemülés forditott görbéjére mutatnak rá e próféták".

\section{5. „Boldog vándor”}

Assisi Szent Ferencet, aki otthonának, hazájának, Umbriának a „szerelmese”, életrajzírója, a kortárs ferences, Celanói Tamás „,felix viatornak”, boldog vándornak nevezi. Ugyanez és ugyanígy mondható el Szedő Dénesről is. Úgy van itthon ezen a földön, úgy hazája ez a haza, hogy közben állandóan búcsúzik is tőle, búcsúzóban van. De ettől nem kevésbé van itt itthon, és nem kevésbé hazája ez a haza. E kettősség gyönyörü egységét jól érzékelteti a Szent Ferenc Naphimnusza ihlette, magyar népdalra írt gyermekverse, melyben e teremtett világ, mint Isten dicséretére méltó otthon tárul elénk, szép és vonzó, de ennek a szépségnek és vonzásnak épp az a titka, hogy arra mutat, ahonnan a szépsége és vonzó-volta fakad. A Csillagoknak teremtője c. ugyancsak magyar népdalra írt gyermek-remek második versszakában énekli:

\section{„Földjeinkbe belészántott \\ Szépségéböl egy szilánkot."}

A már említett Naphimnusz-parafrázisban épp a legbelevalóbb, legidevalóbb, legszilajabb teremtmény a leghazahúzóbb, a leg-el-fölfelé-húzóbb:

\section{„Dicsérjen vad öcskösünk, a daloló Tüz: \\ Jókedvében messze fénylik, éjet számüz; \\ Hatalmas és fiatal, lobogó lángjaival \\ égfelé húz",}

oda, ahol a Hold és a csillagok ,,világolnak”, és a Nap tündököl, melyröl zengi:
„Hintve arany sugarat,
jelenti szent Magadat,
szerelmében."

E szerelem vonzásában énekli, mintegy a tüz lobogó vágyával, hogy

$$
\begin{aligned}
& \text { „oda való vagyok én, } \\
& \text { ahol ragyog az a fény, } \\
& \text { biztatólag”. }
\end{aligned}
$$

Lényének ezt a búcsúzó varázsát ragadta meg Szerb Antal az Utas és holdvilág c. regényében, melyben Ervinről - aki később a regényben Szeverin néven ferences lesz - írja, hogy „,mindig mintha búcsúzott volna [...], mintha [...] utoljára csinált volna mindent ezen a világon” (SZERB 1959, p. 45). Zárójel nélküli zárójelben jegyzem meg, hogy az Utas és holdvilágra azért érdemes odafigyelni, mert a 
legautentikusabb, maga Szerb Antal vallotta, hogy Ervin-Szeverin mintája a Szedő testvérek voltak, különösen is Mihály, aki később Dénes néven lett ferences (lásd NAGY in SZERB 2001).

Épp e búcsúzó létállapot az, ami sokszorosra tágítja a szív meglátó képességét, az átélés, az itt-lét intenzitását. Ahogyan Illyés Gyula fejezi ki Kháron ladikja egyik - amúgy Szedő Dénestől igen-igen szeretett - négysorosában:

„Minden oly gyönyörü, söt - titkosan - ahogy

elleng, még gyönyörübb!

Olyformán, mint a dallam attól, hogy ott

hagyja a hegedüt."

Vagy ahogy Tarkovskij Rubljov c. filmjében a Szentháromságot (a kolostort) elhagyó szerzetesek közül Danyiil megjegyzi:

„Így van ez, itt van például ez a nyirfa. Elmégy mellette majd minden nap, észre se veszed, de ha tudod, hogy nem látod többé - szépséges szépnek látod."

Ez a búcsúzón-lét, ez a megragadva elengedés, ez a súlytalan súlyosság jellemzője Szedő Dénes költészetének, mint ahogy személyiségének is. Ezt árulta el a járása is: Úgy ment, mint

„, aki egy kicsit a saját élete fölött jár. Nem túl magasan, ó, dehogyis a fellegekben, hanem csak éppen hogy, egy-két pihényi magassággal halad a nyomorult mindenség fölött, mintha úgy lenne ura az egésznek, hogy közben szolgája is."

(DARVASI László: Csak menni, menni)

A „Vándorok törvénye” szerint jár-kél:

\author{
„Idegen födél alatt \\ húzd meg úgy-ahogy magad, \\ de még virradat elött \\ titkon kelj föl, cihelödj \\ s indulj! Tied út és táj. \\ Csak hazáig meg ne állj." \\ (Vándorok törvénye)
}

\title{
6. „Befogad s kitaszít a világ”
}

Szerb Antal az Utas és holdvilág c. regényéhez Villon Ellentétek c. verséből veszi a mottót, melynek minden versszakban ismétlődő utolsó sora: ,befogad s kitaszit a világ” (ford. Szabó Lőrinc). A kitaszítottságot Szedő Dénes hogy éli meg? Van egy verse, melynek nem engedett nyilvánosságot, kéziratát sose láttam, ritkán elmondta, csöndes beszélgetésekben, szinte szégyellősen. Barátai között közkézen forgott egy olyan változata, melynek befejezése ez volt: „, bő kámzsámba temetem orcámat”. Én így hallottam a verset Szedő Dénestől:
„Zsidó voltam, sem ember, sem állat,
Nyomon kísért szánalom, utálat,
Papnak álltam, lehúzták csuhámat,
Nem találtam, e földön hazámat."

Miért nem találta érettnek, közlésre érdemesnek ezt a verset? Arany János - aki Szedő Dénesnek mindvégig poétikai tankönyve, gyönyörüsége, olvasmánya - hagyja abba úgy a lánya halálakor írt Juliska emlékezete c. versét, hogy alájegyzi:

$$
\text { „Nagyon fáj! nem megy!” }
$$


A nyers fájdalom, a keserüség, a disszonancia önmagában még nem elégséges feltétele annak a harmóniának, melyben költészetté, költeménnyé érik az érzés, a coincidentia oppositorum gyümölcseként. A Lapszéli jegyzet Jób könyvéhez c. esszéjében írja, hogy , a harmónia lényege épp a disszonáns feszültségek kiegyenlitése”. Ameddig csak arra a megállapításra tud jutni, hogy „,itt a földön nem lelém hazámat”, addig az érzés, a gondolat - Szedő Dénes ítéletében - nem vers-érett. Meg kell találni a választ arra, hogy ha itt nem, hát hol igen. Merre? Innen el? Megkísérelte.

1935. december végén levelet fogalmaz tartományfőnökének, melyben Bolíviába kéri magát misszióba. A megokolásban nincs benne, hogy nehezen viselné itthon a zsidó-volta miatti idegenkedést, nem hivatkozik arra, amiről az Utas és holdvilág pater Szeverinje beszél, hogy ,akadtak rendtársaim, akik éreztették velem, hogy mennyire idegenkednek a fajtámtól” (SZERB 1959, p. 130). Akadhattak. Másra hivatkozik. Arra, hogy ő „gyenge legény”, és ha továbbra is a ferencesség ezen elpuhult, fellazult magyarországi változatában marad, ő ebben elzüllik, ezért kéri magát a szegényebben, szigorúbban élő, s jobban a legszegényebbeket szolgáló dél-amerikai ferencesek közé. Kérése oly finom, hogy tálcán kínálja az elutasítást, ami meg is érkezik, a tartományfőnök, bölcsen a hazai misszió lehetőségeire hívja föl a figyelmét. Népmisszionárius lesz, többfelé tart lelkigyakorlatokat, kórházi lelkészként a legelesettebbeket istápolja:

\section{„Mindezek során közvetlen kapcsolatba kerültem a nép minden rétegével. Megismertem s megszerettem öket közös emberi sorsukban, a szenvedésben. Ök tanitottak meg igazán papnak lenni, vagyis a 'megalázottak és megszomoritottak' sorsát viselni, sorsán könnyiteni a puszta jóság és szépség fegyvereivel.” (SZEDÖ 1948 in BOROVI 2002, p. 264)}

Ezek a sorok abból az életrajzból valók, melyet a külügyminiszternek fogalmazott 1948. május 19-én, kérve, hogy bízza meg a „,párizsi magyarok lelki gondozásával”. A kinevezés 1948. augusztus 2-án meg is érkezik, de kiutazni már nem tud, az új hatalom már nem járul hozzá.

E gyengéd menekülési kísérletek kudarcot vallanak.

„Futsz az Úrtól hasztalan”

- kezdi az útra találás, a hazatalálás énekében, a Keresztútban.

„,Mit futsz,

merre nincs út?"

- kérdi, a Soliloquium c. versében. S látja, a menekülés tévút:

„Rézsút tértem, Jézus”

- írja ugyanott. De épp e tévutak járulnak hozzá ahhoz, hogy a Merre? kérdésre ne „kifelé”, hanem „befelé” keressen, otthonosságot ne valahol, hanem Valakiben keressen, abban, aki az „út”. Hogyan hagytam el a világot? c. esszéjében olvashatunk arról, hogy gyermekkora döbbenete Jézusnak ez a mondása:

„Én vagyok az út, az igazság és az élet.” (Jn 14,6)

Szentírása glosszájában így rendezi e három szót:

„Én vagyok az út, mely az igazsághoz és az élethez vezet."

Jézus az Út:

„,Hegytetön, hol nincsen út,

elnyúlt testem ingyen Út."

(Futsz az Úrtól hasztalan - Keresztút)

A velünk sorsközösséget vállalva poklainkra alászálló, megdicsőülö Jézusban, a jézusi sorsközösségben talál otthonra. 
Benne, a vele történtek értelmet kapnak. A „zsidó voltam, sem ember sem állat, nyomon kisért szánalom, utálat” abban a Szenvedő Szolgában, akinek ,,láttán sokan megborzadtak”, mert „,nem volt emberi ábrázata, megvetett volt, [...] aki elöl iszonyattal eltakarjuk arcunkat" (Iz 52,14; 53,3); a „papnak álltam, lehúzták csuhámat” abban, aki így inti s vigasztalja a Keresztút tizedik, a Jézust megfosztják ruháitól állomásában:

$$
\begin{aligned}
& \text { „Mért csupán az ingem kell? } \\
& \text { Ölts magadra Engem fel." }
\end{aligned}
$$

A megérkezés, a hazaérkezés éneke a 27. zsoltár parafrázisa:

$$
\begin{aligned}
& \text { „Apám, anyám elhagy: } \\
& \text { oltalmamra itt vagy. } \\
& \text { Véled engedj laknom, } \\
& \text { nálad vagyok otthon." }
\end{aligned}
$$

Az utolsó Naplófüzet pedig ezzel a „táncdallal” kezdődik:

$$
\begin{aligned}
& \text { „Egyiptomból szabadulva } \\
& \text { Hazatalál immár Juda, } \\
& \text { Ösvény támad tenger árján. } \\
& \text { Táncol a domb, mint a bárány. } \\
& \text { Nincs hatalom Isten elött } \\
& \text { Megfut a viz, reszket a föld, } \\
& \text { Sziklatetö válik tóvá, } \\
& \text { kopár köszirt csobogóvá.” } \\
& \quad \text { (Zsolt 114, parafrázis) }
\end{aligned}
$$

$\mathrm{Az}$ „, itt e földön nem lelém hazámat” és a „, hazatalál immár Juda” harmóniájában már meg tud születni a nagy vers, a Hátán háza, és sorra a többi.

Ha nincs a rosszhír: , kitaszit a világ”, vajon felfogható-e a Jóhír. Izaiás próféta könyvének 56., 66. és 43. fejezetének ihletében születik 1976 márciusában a Jóhír c. verse:

$$
\begin{aligned}
& \text { „Idegen vagy bár, } \\
& \text { s üres kézzel állsz, } \\
& \text { kiaszott fa mégse vagy. } \\
& \text { Hozzám szegödtél: } \\
& \text { szent hegyemre viszlek, } \\
& \text { házamba helyezlek, } \\
& \text { térdemen ringatlak. } \\
& \text { Ne félj!” }
\end{aligned}
$$

Haláláig tanulja Kempis Tamásnak a Krisztus követéséről címü, ,,együgyü szókkal, de csuda nagy lelki bölcsességgel" (ford. Pázmány Péter) megírt könyvecskéjét. Az 1943-as kiadású, kétnyelvü (latin Pázmány-magyar) Franklin-kiadást olvassa. Az 1970-es Naplófüzetben található ez a kiemelt, felkiáltójeles összetett szó:

$$
\text { „Nulla-pont!” }
$$

Utána latinul is, magyarul is kijegyzetelve Kempisből a következő:

„Mert leginkább akkor folyamodunk a mi belső bizonyosságunkhoz, az élő Istenhez, mikor külsőképp semminek tartatunk az emberektöl, és elöttük hitelt nem nyerhetünk."

Az utolsó hetekben gyakran énekelgette, dúdolta azt a magyar népdalt, amelyre ráírta Dávid dalát: 


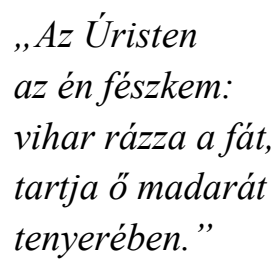

Aki a kitaszítottságból megérkezik a befogadottságnak ebbe a békéjébe, az maga is tárt-ölelésü befogadóvá válik, olyan világot teremtve magában és maga körül, mely befogad. A „,Nálad vagyok otthon” valóságából következett az, hogy mi pedig nálad „Déneske” - egyszer hadd írhassam le így is - voltunk otthon. Hadd folytassam vallomásszerüen. Miért volt jó a te lény-eged alatt élnünk? A leglényeged miatt, mert a te leglényeged, ahogyan Vasadi Péter írja a Közelitó szavak Szedö Dénesröl c. emlékezésében:

„Leglényeged [...] Jézus Krisztus. [...] öérte soroltál minket is testvéreid közé, [...] öt szeretted az emberben, öt kerested bonyolultságainkban, mint az egyetlen Egyszerüséget, és mégis mindent önmagáért szerettél, a ceruzát, mert ceruza, a madarat, mert madár [...]. Mindent és mindenkit Uradban vettél észre, benne szerettél. Érte éltél velünk, neki éltél közöttünk."

(VASADI 1985, pp. 54-55)

\section{Magára találás}

Ez az otthonra találás, ez egyszersmind a magára találás is. Ez érik be. Az 1970-es Naplófüzetben találjuk Giuseppe Ungaretti Mattina (Reggel) c. kétsorosát:

\section{„Mi illumino}

d'immenso."

Fordításának négy változatát találjuk az oldalon, s végül bekeretezve, és Rónay György fordítását („Végtelenséggel / hajnalodom”) is közölve az ötödiket, a végső változatot:

„Atderengek

végtelennel."

Ez ő. És mert ez ő, képes másban is fölfedezni, s megénekelni ezt az átderengést:

$$
\begin{aligned}
& \text { „Átüt brokáton, selymeken } \\
& \text { a nyilt, paraszti jóság; } \\
& \text { át a halandó emberen } \\
& \text { az örökkévalóság” }
\end{aligned}
$$

- írja XXIII. János c. versében. S akik látták haláltusájában, azok a Szenvedő Szolgáról, Jézusról írt versében őrá ismertek:

„Nincs színe, bája: önnön árnya csak [...] mint ragyog mégis?”

(Nincs szine)

Szedő Dénes úgy érik be, úgy formálódik át, hogy régi énjéből semmit sem tagad meg, így abból semmi sem vész el, csak átalakul, megnemesül. Az utolsó Naplófüzetben többször idéz egy-egy Shakespeare-drámából. Ezek a részletek többnyire arról szólnak, hogy a rossz hogyan épül be a jóba. A disszonancia hogyan szolgálja a harmónia, a béke beérését, a coincidentia oppositorum törvénye szerint. Egy helyütt a Romeo és Júliából a barát monológját idézi:

„Ó - nincs a földön oly silány anyag,

mely így vagy úgy ne szolgálná javad;

De nincs oly jó, melyben ne volna vész, 


\section{Ha balga módra véle visszaélsz! \\ A virtus bün, ha jó irányt feled, \\ S a bün-jó úton-virtussá lehet."}

Akik ismerték az ifjú Szedő Mihályt, és ismerték a ferencessé lett Dénest is, ők tudnak erről az összeegyeztethetetlennek tűnő, és mégis egybeérő két világról hiteles képet festeni. A jól ismerők közé tartozik Szerb Antal. Amit regényében Ervin-Szeverinről leír, az hiteles kép:

„Ö volt a legintelligensebb az intelligens és beképzelt fiúk közt. [...] Ervin nagyon szép volt, elefántcsontszínü arcával, magas homlokával, izzó szemével. És áradt belöle a különösség, a dac, a lázadás. És amellett kedves és finom [...] kedvenc szerepe a vadállat volt [...], az ivásba épp oly szenvedélyesen vetette bele magát, mint a dohányzásba. [...] Ervin volt a hegemón, öt tartottuk magunk közül a legkülönbnek.” (SZERB 1959, pp. 41, 43-44, 53)

Az Utas és holdvilág végén Ervin már Szeverin néven ferences szerzetesként jelenik meg. A regénybeli Mihály, akit Szerb Antal magáról mintázott, nagy válságában elmegy Gubbióba, hogy felkeresse Szeverint. Poszler György Szerb Antalról írt monográfiájában mondja el azt, amiröl Szedő Dénestől magam is hallottam, hogy „Szerb magányra szomjazó korszakaiban hozzá és testvéréhez, Szedö Lászlóhoz kerül a legközelebb” (POSZLER 1962, p. 385). A regénybeli gubbiói beszélgetés elárul valamit ebből a közelségből. Mihály feltárja benne, mennyire ,elhibázottnak érzi felnött vagy ál-felnőtt életét, házasságát, mennyire nem tudja [...], hogyan térhetne vissza igazi önmagához”" (SZERB 1959, pp. 132-133). Ezek a szavak emlékeztetnek Szerb Antal naplójának azon részleteire, amelyeket akkor ír, amikor huszonhárom évesen beleszalad egy - szerencsétlen házassággal, válással végződő - olyan kapcsolatba, melyet összeegyeztethetetlenek tart katolikus hitével:

„Általláttam azt a szörnyü igazságot, hogy többé már nem vagyok kisfiú [...] és itt állok Isten-elhagyatva egy érthetetlen mindenségben. De ezen nem lehet segíteni. Élni kell az ópiumokkal."

De az ópiumok sem segítenek, ezért keresi fel az Utas és holdvilágban Mihály a régi jó barátot, Ervint: „Ervin mindenre fog irt tudni.” (SZERB 1959, p. 124)

Mihályt megdöbbenti az a változás, ahogyan Ervin Szeverinné alakult:

„Pár perc múlva megérkezett Ervin [...] a ferencesek barna csuhájában. Mihályt csak most ütötte meg, hogy Ervin mennyire ferencrendi. A tonzúra egészen más jelleget adott az arcnak, magában is kiölt belöle minden világiasságot, minden e világiasságot, és a Giotto és Fra Angelicók levegöjébe emelte fel, és mégis. Mihály úgy érezte, hogy ez Ervin igazi arca, kezdettöl fogva erre az arcra készült, a tonzúra mindig is ott volt a fején, csak akkor még eltakarta Ervin kondor, fekete haja. [...] Nem volt kétséges, hogy Ervin megtalálta önmagát." (SZERB 1959, p. 127)

Szedő Dénes bátyja, Szedő László Szeverin, aki kármelita szerzetes lett, szóban és írásban is megerősítette azt, hogy az Utas és holdvilágban hitelesek Szerb Antal leírásai az öccséről, Dénesről. Az öccse nekrológjának készült $A$ kisebb testvér c. írása. Benne olvassuk:

„A serdülö fiú, majd a fiatalember hirtelen nöni kezd, az esze megnyílik [...], önállósitja magát, mászkál a barátaival; van úgy, hogy el is költözik hazulról. Nem birja a kötöttségeket. Verseit leközli a Nyugat; az elnyomottság alól felszabadult temperamentum forrni kezd." (SZEDÖ 2005)

Később a két testvér László, a „bátyó” újmiséjén találkozik. Erről így ír a nekrológban: 


\begin{abstract}
„,Mikor újmisémen egy fiatal franciskánus barát jelent meg a szószéken-aszkéta arc, nyúlánk termet - teljesen megzavarodtam. Az öcsém volt az, a kisebb testvér. Egy más, kicserélt ember [...], egy kiegyensúlyozott, kissé szomorú, végtelenül szelíd és bölcs ember állott elöttem. Megszerette a szelídséget, a szépséget és a jóságot életvitelében, eljárásaiban, holott alaptermészete inkább hirtelen fellobbanó, erélyes embernek igérte. [...] Végre láttam olyan embert, aki nem csak igérgette, hanem meg is valósitotta megtérését, 'megfordulását'." (Uo.)
\end{abstract}

\title{
8. Erő a szelídségben, erő az egyszerüségben
}

A tüz azzal, hogy nem felperzsel, hanem „ég felé húz”, semmit nem veszít erélyességéből, szenvedélyéből, lobogásából, sőt! Ott van az erő a szeretetében. Nemeskürty István mondta el, hogy az ötvenes évek elején Szedő Dénessel, Pilinszky Jánossal együtt nevelősködött György Júlia intézetében, mely a háborúban, a megtorlások következtében árván maradt, és elhagyatottságukban többnyire vadóccá vált fiúknak adott otthont. Kérdéses volt, hogy képes lesz-e ez a szelíd, törékeny ferences úrrá lenni e vad csapaton. Képes volt. Segített ebben múltja is. Nem kellett lexikonokhoz nyúlnia ahhoz, hogy megtudja, mi ez a lázadó, kötöttségeket nem türő szertelenség. Magából kiindulva tudta megérteni a fiúkat, s e megértéssel, a minden egyes gyereket külön-külön fogadó, elfogadó megértő szeretettel ö győzött. Nem a vadak vadították el, hogy köztük csak így lehet, hanem a bárány győzött. Szelídsége bölcsességével és erejével ő lett úrrá a vadságon.

Az erő megnyilvánulása a türelem, az ahogyan „szerelmében béketürő” (Nap testvér éneke). A szenvedései valóban magot érlelők voltak, akár a nagy versek értelmében is. Ezt ő Naplófüzetében így nyugtázza:

„,Türvén sokat, terem a mag."

Az erő, erélyesség, szenvedélyesség ott van a megalkuvást nem ismerő igényességében. Kérlelhetetlen, ha a minőségről van szó. A Kodálytól kapott héber dallamra írt Naphimnuszt énekeltük úgy, hogy megtördeltük levegővétellel a sorok közepét.

$$
\text { „Megtörni e dallamfolyamot?" }
$$

- lelki, testi fájdalmat árult el a tekintete, miközben kijelentette:

„Ha csak igy tudjátok énekelni, ne énekeljétek!"

Aki az emberi gyengeség, botlás isteni irgalmú megértője volt, egy prozódiai vétséget, ritmikai botlást megbocsáthatatlannak tartott. Önmagához is könyörtelen volt. Haláláig javított, tisztázott.

Az erő ott van írásai magszerü tömörségében, rövidségében. Minél rejtőzőbben, annál robbanékonyabban:

„Fényre jö, mi lappang,

$s$ a titok kipattan"

- olvasom a Viruló igék egyikében.

Szedő Dénes egyszerü. Milyen értelemben? A szónak szószerinti értelmében: Egy-szerü. Mi ennek az egyszerüségnek a forrása?

„Söma Jiszrael! Adenoj eloheinu adenoj echod.

Halljad Izrael! Az Örökkévaló, a te Istened, az Örökkévaló egyetlenegy."

(MTörv 6,4)

És mindez, mint legdrágább, felejthetetlen, legszemélyesebb kincs, bejegyezve az utolsó Naplófüzet utolsó lapjára, reszkető kezekkel leírva héberül is, magyarul is, mindkét anyanyelvén. És így ez a hat szó azt a jelentést kapja, hogy az Örökkévaló, az Isten az ő Istene, az Örökkévaló az ő Egyetlene. Ö pedig az Örökkévaló egyetlene, szemefénye. Lásd: Jóhír. Ebből a szeretetből fogan Szedő Dénes 
egyszerüsége. Ebben az egyszerüségben nincs semmi együgyüség, egyszínüség, egyhangúság, hanem a pattanásig feszülő ellentéteknek teremtő békéje, színek és hangok szivárvány harmóniája, egysége. Az utolsó versek egyike a magyar népdalra írt talányos vers, a Merre?:

$$
\text { „La 'la'mi / re mi / re re la / szo la / do do re la. }
$$

Mi a megfejtése? Ha fölemelkedni akarsz, indulj „lefelé”, a szeretet mindig alászáll. Ha az elsők közt akarsz lenni, akkor menj „, hátra” az utolsók közé, mert az üdvösség törvénye, hogy az utolsók lesznek elsők. Ha kitünő akarsz lenni, akkor válj belső emberré, vagyis az irány „,befelé”. A jobb sors titka pedig, hogy vállalj sorsközösséget a balsorsúakkal, mint Jézus, ezért fordulj „,balra”.

\section{Joculator Domini}

Hová soroljuk Szedő Dénest, a költőt? Ha valaki pap és költő, rámondjuk, hogy papköltő, és máris szimatolunk írásaiban valami papos-lapost. Szedő Dénesnél ennek nyoma sincs. Ha valaki katolikus és költő, rámondjuk, hogy katolikusköltő, és máris szimatolunk írásaiban valami jámbor oktató igyekezetet. Szedő Dénesnél ennek nyoma sincs. Mit mondjunk arról, aki katolikus is, pap is, mindez ferences szerzetesként és költő? Szedő Dénes a válogatott írásainak, a Facimbalomnak a fülszövegében írja:

$$
\begin{aligned}
& \text { „Életem egyik nagy - ha nem a legnagyobb - ajándéka az volt, hogy szent Ferenc } \\
& \text { a családjába fogadott." }
\end{aligned}
$$

Szedő Dénes tehát ferences költő.

Assisi Szent Ferenc élete utolsó évének egyik éjszakáján, testi-lelki szenvedéseinek a mélypontján, azon a bizonyos null-ponton, váratlanul, meglepetésszerüen ígéretet kap, s vele együtt kibeszélhetetlen örömöt, az üdvösség ígéretét, az üdvösség örömét. S ebből az örömből pattan ki a Teremtmények dicsérete, a Naphimnusz, Ferenc „beöltözött a mindenség örömébe” (vö. Pilinszky János: Az okos utazókról). Hajnalban „,költó óriás” (uo.) születik. Ferenc diktál, s nyomban küldi is a testvéreket, hogy ahol csak tudják, énekeljék az Úr dicséretét, mint az Úr énekmondói, joculatores Domini:

\section{„Mert hát mi mások a kisebb testvérek, mint az Úr jokulátorai." \\ (Assisi Szent Ferenc perugiai legendája, XLIII.)}

A 13. századi jokulátorok komédiások, bohókás, tréfás és többnyire szerelmes dalok szerzői és előadói. E dalok nem álltak messze Ferenctől. Megtérése előtt, társaival beharsogja velük Assisi éjszakáját. A Carmina Burana énekei ízelítőt adnak a jokulátorok repertoárjából. Később, éppen Szent Ferenc nyomán a jokulátoroknak két tábora alakult ki, a világi és a misztikus énekmondóké.

Szedő Dénes ez utóbbiakhoz tartozik, joculator Domini, az Úr énekmondója, az Úr 20. századi énekmondója. Ez több szempontból is megállja a helyét.

\section{1. Énekmondó}

Versei énekelnek. Teljes bennük a kép és a zene összhangja. Legtöbb verse ének is. Vagy úgy keletkezett, hogy először a dallamot kapta, és arra készítette a verset, mint a Napéneket. Kodályról szóló megemlékezésében írja:

$$
\begin{aligned}
& \text { „'46-ban, Pesten egy szövegtelen kis vegyeskart adott a kezembe; akkoriban írta } \\
& \text { egy ötfokú héber dallamból. 'Próbáljak-mondotta-valami zsoltárszerü magyar }
\end{aligned}
$$

7 Többet éppen Szedő Dénes fordít magyarra (lásd SzEDŐ 2011, pp. 115-127). 
szöveget irni a hangjegyek alá.' Szent Ferenc Napénekéböl formáltam hozzá verset: 'Nagy jó Úristen'." (SZEDÖ in BÓNIS 1994, p. 217-220)

Van úgy, hogy a versek vonzották a dallamot. Mély barátság füzte zeneszerzökhöz. Az említett Kodályon kívül Kerényi Györgyhöz, Bárdos Lajoshoz, Ádám Jenőhöz. Több verséhez ő keresett dalt, többnyire a magyar népdalkincsböl, de találunk versei alatt görög, finn, csuvas, lapp, cseremisz, indián, ókaliforniai, erdélyi román, szlovák népdalokat; a gregorián dallamok sem ritkák.

Költészete igazi líra. Abban az értelemben is, hogy a líra szó, a görög zeneszerszám, a lantszerü lyra megnevezéséből ered. Szedő Dénes dalait maga kísérte, egy kétsoros, fa hangzórudakból álló xylofonon. Ezt nevezte facimbalomnak, és innen az 1981-ben megjelent válogatott írásainak címe is, a Facimbalom. Több verse készült képek ihletében. ${ }^{8}$ Ezekben tovább festi a képet, ahogyan benne a kép képet fakaszt, egyesülve egy belső dallal. Amit Bartókról ír a Dallam ködgomolyagban c. versében, az rá is áll: „,Fülel egy belsö dalra". Van, hogy megnevezi e folyamatot, mint a Lány kalitkával c. vers Rippl-Rónai kép ihlette misztikájában. Több verséhez rajz is társul. Egy részüket neves képzőmüvészek készítették. A Királyocskám 1944-ben megjelent énekfüzethez a rajzokat Kákonyi Konstantina készítette, az 1947-ben megjelent Kirelejszomhoz pedig Borsos Miklós. Nem ritka, hogy írásaihoz maga készíti a rajzokat. ${ }^{9}$

Az abszolút hallás, a szöveg és zene együtthallásának remekei a dallamokkal vagy dallamokra írt versei mellett a himnusz, antifóna, szekvencia fordításai. Ezekben dallam és szöveg - sajnos - ritka összhangjával ajándékoz meg. Szedő Dénes Bárdos Lajostól prozódia tankönyvet kért. A tankönyvet Bárdos megküldte egy levél kíséretében, melyben ez állt:

„Igazán nem tudom, hogy egy Szedö Dénesnek miért kellene prozódia-tankönyv, amikor neki ösztönösen, égböl adottan, a kisujjában, a szivében és a tolla hegyén van minden tudnivaló."

Van olyan antifóna fordítása, melyröl - bármilyen meghökkentő - túlzás nélkül állítható, hogy jobban simul a gregorián dallamhoz, mint a latin eredeti. Ilyen pl. a Szeplötlen anyánk, a Salve Regina fordítása, a Jöjj el, jöjj el, Emmánuel.

\section{Isten bolondja}

Szedő Dénes egész habitusában volt valami az énekmondók hol könny-, hol mosolyfakasztó bolondságából, mely játék is, üzenet is, mindenképpen egy szerep, olyan szerep, amellyel egyre elmélyültebben azonosult, ahogy az Utas és holdvilág Ervinjéről olvassuk:

„Egész életével meg akart játszani egy szerepet, [...] és a szerep befelé egyre mélyült." (SZERB 1959, p. 42)

De nála a mosoly és a könny nem váltakoznak, hanem együtt vannak jelen. Utolsó Naplófüzeteiben vissza-visszatér Weöres Sándor egysorosa:

„Isten rajtad: végtelen könny; Isten benned: végtelen mosoly."

(Weöres Sándor: Egysoros versek, IV.)

Szomorúság és mosoly együtt voltak benne jelen a „Boldogok, akik sirnak” (Mt 5,4) megéléseképp. Ez sugárzik múveiből is. A mosoly és könny együttese hol rejtettebben, hol nyilvánvalóbban jelenik meg, mint például itt:

$$
\begin{aligned}
& \text { „Nincs színe, bája } \\
& \text { önnön árnya csak. } \\
& \text { Mint ragyog mégis!” }
\end{aligned}
$$


(Nincs szine)

Vagy az Ubi caritas c. versében:

„,Valahol könny perdül

megriadt öz szembül,

ott az Isten."

Tudjuk, hogy a Barabások világában Szent Ferencnek előkelő hely jutott. Az Utas és holdvilágban olvassuk: Mihály

„Assisibe jövet abban reménykedett, hogy itt talán megtalálja Ervint. Hiszen

ifjúkorukban, amikor Ervin volt a hegemon, elolvastak mindent, amit Assisi nagy

szentjéröl el lehetett olvasni. Ervin bizonyára ferencrendi szerzetes lett."

(SZERB 1959, p. 82-83)

Szerb Antal írásaiból azt is tudjuk, hogy mi ragadta meg e lázadó fiatalokat Szent Ferencből. A lázadó volta, de az, amely nem kívülről szított, nem a külső viszonyok miatti elégedetlenségtől hergelt, és nem is forradalmi megsemmisítésekre bújtató. Idegenné válik tőle (tudjuk nála sem egy csapásra) mindenféle pusztító harag, fölháborodás. Az ő lázadása belülről fakadó, belső szabadságot teremtő lázadás. Megismerte Jézust, és ezentúl csak, és csakis neki akart megfelelni, az ő normája szerint akart normális lenni, az ő ítélete, bölcsessége szerint akart bölcs lenni, ebböl következett, hogy az ennek ellentmondó norma, a pénzben, piacban, rangban, hatalomban és dicsőségben gondolkodó világ normája szerint neki abnormálisnak, e világ bölcsessége szerint pedig bolondnak kellett lennie. És ez az, amit Ferenc dalolva vállal.

Szerb Antal, Chesterton Szent Ferencröl írt könyvéröl szólva - és azonosulva is e könyv szellemiségével - írja, hogy a „,régi ferencesek Isten nagyobb dicsőségére és polgártársaik örömére bolondnak tetették magukat" (SZERB 1935, p. 130). Leírja e bolondság mibenlétét is:

„Az embernek a feje tetejére kell állnia, és örült költönek kell lennie, ha úgy akarja látni a dolgokat, amint csakugyan vannak: mert aki a lábán áll, és nem örült költö, az csak a konvencionális vonalakat látja, és nem azt a bohókás és egyben minden emberi mérték fölött monumentális valamit, ami a valóság."

(SZERB 1935, pp. 129-130)

És hogy mi ez a „minden emberi mérték fölött monumentális valami, ami a valóság”, arra abban az írásában ad Szerb Antal feleletet, melyben emlékezik ifjúságuk világára, a Barabások világára:

„Assisi Szent Ferenc, amikor a börtönböl kiengedték, elvböl bolondosan viselkedett és szeretett a feje tetejére állni [...] a tótágastól egyenes út vezet az Alverna hegyére, a stigmákhoz." (SZERB 2002, pp, 164-165)

Szedő Dénes egyszer arról beszélt, hogy látta a „bolondok házában”, hogy a lakók közül többen, egyszer csak váratlanul terpeszbe vágták magukat, lehajoltak és terpesztett lábuk között néztek ki, fölfelé. Ö is kipróbálta, próbáljam ki én is. Másként látni a világot, nem föntről lefele, nem lenézed, hanem lentről fölfelé, fölnézel rá. Ez a „bolond” perspektíva, a lentröl fölnéző, ámuló tisztelet ott van Szedő Dénes minden sorában, rajzainak játékos-remegő áhítatában. De ez a „lentről”, ez a lent, a „hegytetôt” is jelenti, a szeretet csúcsát, a szeretetből elviselt, vállalt pokol-járást, a szeretetből bolondulást, a kereszt bolondságát, ,Isten bolondságát, amely bölcsebb az emberek bölcsességénél” (1Kor 1,25).

Aki az „Isten bolondságának” e vonzásában él, az az „Isten bolondja, a szeretet bolondja”, miként a 13. századi katalán ferences költő, Ramon Lull (1233/1234-1315) neveztetik, akinek az Imádónak és Imádottnak könyve c. elmélkedés gyüjteményét Szedő Dénes le is fordítja. Mondhatni „családi vállalkozásban" jelenik meg 1943-ban, a ferences Kapisztrán-nyomda betüivel, Szedő Dénes 
fordításában és bátyjának, László-Szeverinnek a lényeget láttató szép bevezetőjével; a rajzokat a jó barát, Martyn Ferenc készítette.

A „bolondságnak” ebben a világában minden másképp van, mint a „,normális” világban. Erre a „másvilágra” csodálkozik rá a felsős gimnazista, erről a csodálkozásról vall Szerelem címszó alatt a Hogyan hagytam el a világot c. visszaemlékezésében. Nála ez a csodálkozás nem múló életkori sajátosság. Szüntelenül az ellentétek, a „Viruló igék - az Igen és a Nem” világában él.

„Bolond! Valld meg, mi a szeretet? - Olyan dolog a szeretet, ami szabadokat rabul ejt, rabokat pedig felszabadit." (LULL 1943, n. 295)

„Mik a te kincseid? Felelé: A szegénység, melyben Imádottam kedvéért élek. - És mi a te nyugovásod? - A nyugtalanság, melybe a szerelem sodor"

(LULL 1943, n. 57)

- olvassuk az Imádónak és Imádottnak könyvében.

Szedő Dénes öltözéke is elég bolondos volt: lobogó farmer, bö kapucnis kámzsa és valami fura „sipka” a fején. Egyszer azzal fogad, hogy „az az érzésem, hogy engem mindenki bolondnak néz. Hazajövet belenéztem a tükörbe, s láttam, hogy igazuk van”. Nagyon örült e fölfedezésnek. Számtalan változatban készítette el az Isten szegénykéje című, Pálóczi Horváth Ádám dallamára írt Szent Ferenc himnuszt, melyben ezt énekeljük: „,társai nézték Isten bolondjának”. Szedő Dénesre is tökéletesen áll ez a sor.

\section{Szerelem, gyermeki csodálkozással}

A jokulátor a szerelem énekese. A Barabások egy korabeli szerelmes dal egyik soráról nevezték el magukat. A szerelem álma-vágya tölti be őket, ez kiváltképp igaz Szedő Mihályra, a későbbi Dénes atyára. Róla olvashatjuk az Utas és holdvilágban:

„Ervin rendkivül szerette a nöket. Ö volt a szerelmes az osztályban [...]. Szerelmeiröl az egész osztály tudott, mert hiszen egész délután az illetö kislánnyal sétált a Gellérthegyen, és verseket is irt hozzá. [...] Ervinnek egészen különös diszpoziciója volt arra, hogy szerelmes legyen."

(SZERB 1959, pp. 43, 53)

„A lányok is öcsémre vetnek szemet, és fölfütyülnek neki az ablak alatt” - olvashatjuk a „bátyónak”, Szedő László Szeverinnek A kisebb testvér c. visszaemlékezésében, mintegy megerösítve az Utas és holdvilág leírásait.

Azonban a szerelemre diszponált Ervin egy még különösebb szerelemre kap diszpozíciót: „Ervin egy szép napon eltünt [...], szerzetes lett [...], megtette, amiröl annyit ábrándoztunk akkoriban: ifjúságát töretlen áldozatként ajánlotta fel Istennek. [...] Hogyha annyira diszponálva volt a szerelemre, miért hozta meg ezt az áldozatot?" (SZERB 1959, p. 54)

- merül fel a kérdés a regényben, $\mathrm{s}$ a válasz is érkezik:

„A lélekben az ellentétek egymás mellett vannak. Nagy aszkéták nem hideg és szenvtelen emberekböl lesznek, hanem a legtüzesebbekböl, azokból, akiknek van miröl lemondaniuk." (Uo.)

A regény szereplői kusza szerelmeikben inkább elvesznek, mint megtalálják magukat. Ez egyedül a különös „szerelemre diszponált” Ervinről volt állítható:

„Nem volt kétséges, hogy Ervin megtalálta önmagát.” (SZERB 1959, p. 127) 
Egyedül ő tudta elmondani magáról:

„Amint az évek múlnak, egyre nö bennem a béke.” (Uo. p. 130)

Ez a béke, a „tisztult” szerelem békéje, amelyről Angelus Silesius V. 210. párversében Szedő Dénes fordításában ezt olvashatjuk:

$$
\begin{aligned}
& \text { „Az ifjú szerelem újborként zúg s hevül; } \\
& \text { tisztulva s tisztesen: mindinkább csöndesül." }
\end{aligned}
$$

Ez, az egyre növekvő békében mindinkább csöndesülő szerelem sohasem szünt meg énekelni. Utolsó hónapjaiban, sokszor kórházi vaságyakon, felhúzott térde „pulpitusán” is születnek énekek, egy kis spirál kottás füzetbe lejegyezve. Két változatban is megénekli Kempis Tamás Krisztus követése c. könyvéböl ezt a sort:

„Sine dolore non vivitur in amore.”

Pázmány Péter fordításában ez így hangzik:

„A szerelemben nem élhetni fájdalom-nélkül.”

Az egyik változat:

$$
\begin{aligned}
& \text { „Hol könny së gyülik; } \\
& \text { szerelem së nyílik. } \\
& \text { Sohasëm.” }
\end{aligned}
$$

A másik:

„Kín nélkül, úgy lehet, nincs igaz szeretet.”

Az alsó szólamában:

„Kín nélkül nem nyilik szeretet.”

Leromlott állapotát, ereje fogyatkozását ezzel a népdallal tudatja e kottás füzetben:

$$
\begin{aligned}
& \text { „Nád a házam teteje, } \\
& \text { Rászállott a cinege, } \\
& \text { Rászállott a cinege: } \\
& \text { Leszakadt a teteje." }
\end{aligned}
$$

De ezért , „nem veszitjük el kedvünket, bár a külsö ember romlásnak indult bennünk, a belsö napról napra megújul" (2Kor 4,16) - olvassuk az utolsó Naplófüzetben. Az énekes füzetben e páli idézet párja a János-evangélium soraiból szőtt ének:

$$
\begin{aligned}
& \text { „Mig a búzaszem el nem hal a földben, } \\
& \text { termést sose hoz, maga marad árván; } \\
& \text { Ám ha elenyész, élni fog és éltet. } \\
& \text { Tanitja Krisztus.” }
\end{aligned}
$$

Az Itt jelen vagyon (Éneklő Egyház n. 163) dallamára énekelhető. Alsó szólamot is komponál hozzá.

Készül a nagy találkozásra. A találkozásra azzal, akinek szerelmes levelét egy életen át, a gyermek nyitottságával, bizalmával, hitével olvasta:

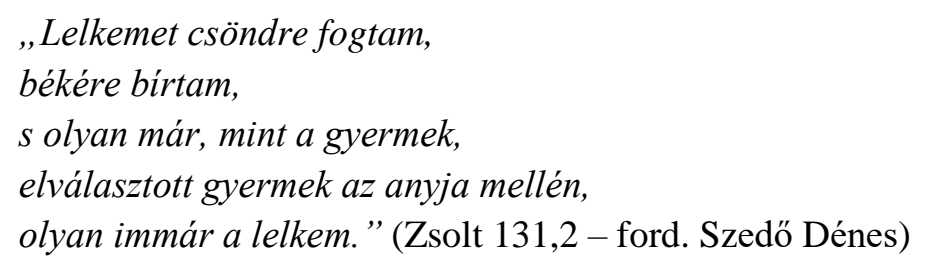

Ezt ajánlotta az Énekek Éneke fordításának előszavában másoknak is: A Szentírást 


\section{„U'gy olvasd, mintha szerelmes levelet tartanál a kezedben. Úgy fogadd be, ahogy}

a gyermek fogadja be, amit lát és hall!” (SZEDÖ 2018, p. 190)

Egyetlen asztalka a szobájában. Pontosan akkora, amekkora kinyitva a Szentírása: betölti az életét. egészen megnyílt ennek az egy Írásnak, s általa az Egyetlennek, tudott megnyílni minden igaz szívből jövő, s a szívnek megfelelő írásnak. E nyitottság tanúi a müfordításai.

Szedő Dénes szorgalmas képtár látogató volt. Nem száguldó képfaló. Ha egy alkotás megragadta, aznap nála időzött, Naplófüzetébe le is rajzolta, s többnyire vers lett belőle. Féltve örizte, de szívesen mutatta az innen-onnan kivágott műalkotásokat. A gyüjteményét Szívbéli képtárnak nevezte el. Kicsi könyvtára volt, benne volt található S. Nagy Katalin Chagallról szóló monográfiája, benne néhány részlet Chagall imádságaiból. Szedő Dénes ezeket a sorokat keretezte be:

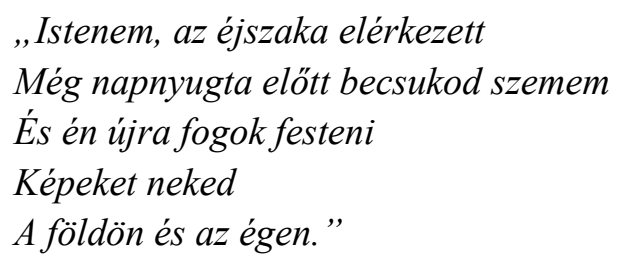

Pilinszky naplójában olvashatjuk:

„Bárkinek irunk: hiedelem. Egyedül Istennek írunk!”

(PILINSZKY 1955)

Ezekkel a sorokkal Szedő Dénes tökéletesen azonosult. Valamennyi írása válasz az Írásra, a „,szerelmes levélre". Utolsó hónapjai készülődés arra, hogy szemtől-szembe láthatja azt, akinek eddig írásait írta, „leveleit” küldte. Amikor tudta, hogy már elkészült a „szép pallut - gyalult - deszka”, a halála közel, kíséretet is írva hozzá, lekottázta ezt a népdalt:
„Hopp ide tisztán
Szép pallut deszkán,
nem lëszek többé nyoszolyó lëány,
ha lëszek, lëszek, menyasszony lëszek,
annak is pedig, legszebbje lëszek."

S e lap alján újra leírja kottástul:

„Kín nélkül,

úgy lehet, nincs igaz szeretet."

Ebben az utolsó Naplófüzetben több gyönyörü álom-leírást is találunk. Ezek közül az egyik:

„Álom.-Költözés. Barna kézitáskámnak - összes írásommal - hült helye.”

Szedő Dénes írásainak kiadásával azon fáradozunk, hogy ezen írásoknak ne hült helye legyen, hanem fogadjuk őket forró szeretettel!

„Azt hiszem, ezt az embert régibb századokban SZENTKÉNT tisztelték volna."

(SZERB 1959, p. 230) 


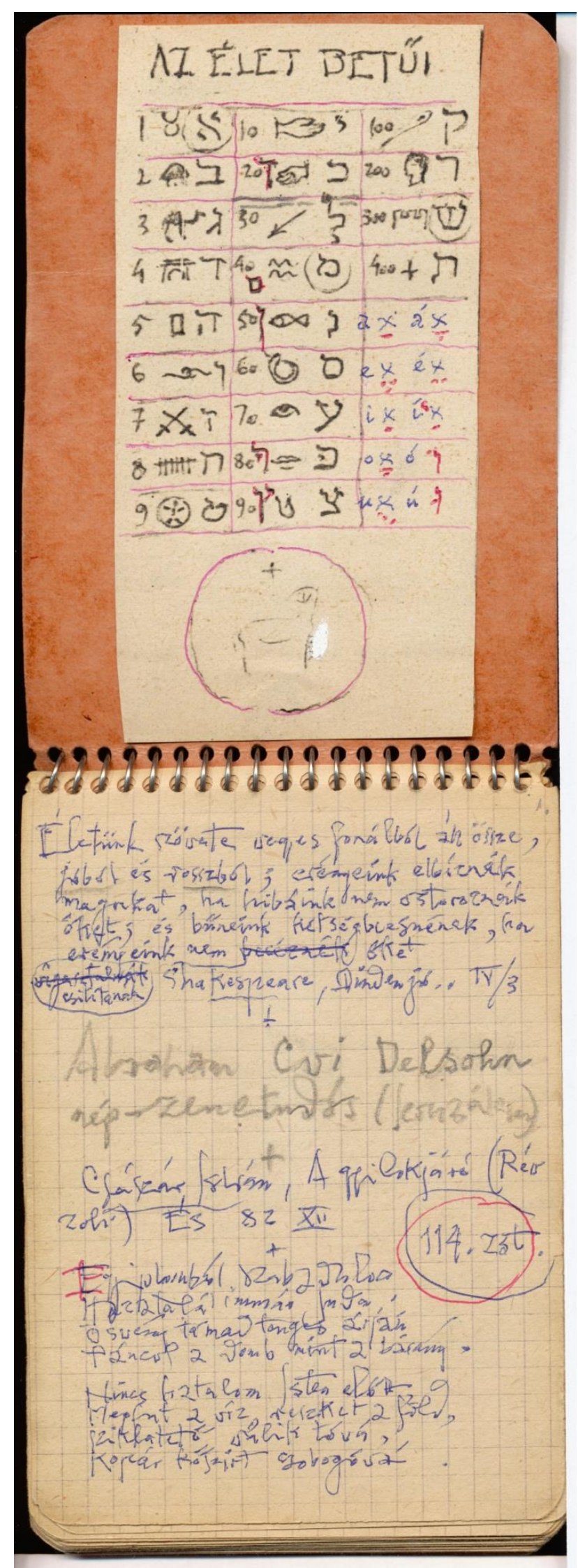

1. kép. Részlet Szedő Dénes naplójából 


\section{Irodalom - References}

BARTÓK, B.: 1943. dec. 17-i Amerikából írt levele.

BARTÓK, B.: 1945. júl. 1-i Amerikából írt levele.

BIELICZKYNÉ BÚZÁs, É. (összeáll.) [s. a.]: Rádiófónia. 75 esztendö a magyar zene hullámhosszán (1925-2000). 4. kötet, Bartók Béla. Budapest, pp. 60-112.

CsoÓRI, S.: Naplók - háttérben Máriával. In: uő (2007): Tizenhét kö a parton. Nap Kiadó, Budapest, pp. 125-134.

FERENC, Assisi Szent \& SzEDŐ D. (1981): Az egyszerüség útja /Facimbalom. Szent István Társulat, Budapest.

KEMPIS, T. (1943): Krisztus követéséröl. Franklin-Társulat, Budapest. (ford. Pázmány P.)

LULL, R. OFM (1943): Imádónak és imádottnak könyve. Szemlélödések a hét minden napjára. A Lelki Élet Ferences Mesterei 11., Kapisztrán-nyomda, Budapest. (ford. Szedő Dénes OFM \& Szedő Szeverin OCD)

MolnÁR, A. (1948): Bartók müvészete. Emlékezésekkel a müvész életére. Elöszó. Rózsavölgyi és Társa, Budapest.

NAGY, Cs. (2001): Ki ölte meg Ulpius Tamást? Avagy töredékek egy irodalmi nyomozás jegyzőkönyvéből. In: SzERB, A. (2001): Naplójegyzetek. Magvető Kiadó, Budapest, 301-305.

PASCAL, B. (1978): Gondolatok. Gondolat Kiadó, Budapest. (ford. Pődör, L.)

POSZLER, Gy. (1962): Intellektualitás és élmény Szerb Antal pályakezdésében. Irodalomtörténet, 5(34): 382-397.

PILINSZKY, J. (1977): Egy lírikus naplójából. Élet és Irodalom, 21(ápr. 9).

PILINSZKY, J. (1995): Naplók, töredékek. Osiris, Budapest.

SÁRKÖZI, Gy. (1921): Fiataloknak. Nyugat, 14(5): 371.

SZEDŐ, D. OFM (1955): 1955. december 29-i levele Kerényi Györgynek.

SZEDŐ, D. OFM (1957): 1957. január 7-i levele Kerényi Györgynek.

SZEDÖ, D. OFM (1983a): 24. Naplófüzet. Kézirat.

SZEDÖ, D. OFM (1922a): Ananké. Nyugat, 15(7): 484.

SZEDÖ, D. OFM (1922b): Bartók Béla zenéjéröl. Nyugat, 15(3): 226-227.

SZEDŐ, D. OFM (1983b): Bónis Ferencnek irt levél.

SZEDÖ, D. OFM (1948): Curriculum vitae az 1948. május 19-i külügyminiszternek benyújtott kérelemhez. Az írás facsimilében megjelent. In: BOROVI, J. (2001): A franciaországi magyar katolikus lelkészségek története II., 1945-2000. Párizs, Lille-Strasbourg-Metz-Lyon. Szent István Társulat, Budapest, p. 264.

SzEDÖ, D. OFM (1983c): Hogyan hagytam el a világot. Új Ember, 39(43/1947).

SzEDÖ, D. OFM (1994): Így láttam Kodályt. In: BÓNIS, F. (szerk.) (1994³): Így láttuk Kodályt. Püski Kiadó, Budapest, pp. 217-220.

SZEDÖ, D. OFM (1972): Kép és hasonlatosság. Új Ember, 28(4/1333).

SZEDÖ, D. OFM (2011): Szedö Dénes összes müvei. 1. köt., Müforditások. Szent István Társulat, Budapest.

SzEDŐ, D. OFM (2018): Szedö Dénes összes müvei. 2. köt., Versek, énekek, prózai irások, levelek, róla szóló visszaemlékezések. Magyarok Nagyasszonya Ferences Rendtartomány, Budapest.

SzEDŐ, Sz. OCD (2005): A kisebb testvér. Új Ember, 60(9/2950). 
SZERB, A. (1935): Hétköznapok és csodák. Révai Kiadás, Budapest.

SZERB, A. (1938): Könyvek és ifjúság elégiája. Nyugat, 31(10) 273-281.

SZERB, A. (2002): Könyvek és ifjúság elégiája. A kétarcú hallgatás. Összegyüjtött esszék, tanulmányok, kritikák. III. kötet, Vegyes tárgyú irások. Magvető Kiadó, Budapest.

SZERB, A. (1959): Utas és holdvilág. Magvető Kiadó, Budapest. (Eredeti megjelenés: Puskin Press, 1937.)

VASADI, P. (1985): Közelítő szavak Szedő Dénesröl. Vigilia, 50(1): 54-55.

A Budapest VI. kerületi Lovag utcai polgári leányiskola értesitöje. 1934-1935.

Assisi Szent Ferenc perugiai legendája (1997). Ferences Források 5., Agapé, Szeged - Újvidék Csíksomlyó. (ford., bev., jegyz. Varga I.) 